\title{
Electrical Porcelain Production From Selected Kaolin Deposit in South Western Nigeria Using Slip Casting
}

\author{
Atanda P. O $^{1}$, Oluwole O. O $^{2, *}$, Oladeji. T. A ${ }^{1}$ \\ ${ }^{1}$ Material Science and En gineering Department, Obafemi Awolowo University, Ile-ife \\ ${ }^{2}$ Mechanical En gineering Department, University of Ibadan, Ibadan
}

\begin{abstract}
The production of Electrical porcelain by slip casting using Ikere-Ekiti Kaolin and clay from South Westem Nigeria was the focus of this work. Atomic Absorbtion Spectrometric(AAS) analyses of samples of Ikere -Ekiti Kaolin and clay, Ile-Ife clay and Iwo Kaolin was done. AAS analyses showed Iwo Kao lin and Ile-ife clay having low alu mina and high impurity contents making them low re fractory. Initial tests confirmed its low refractoriness as Iwo Kao lin could not withstand the bisque firing at $900^{\circ} \mathrm{C}$ cracking extensively. Thus Ile-ife clay and Iwo Kaolin were disqualified as candidate materials for electrical porcelain production. Ikere-Ekiti kaolin and clay found to be high in alumina content and having low impurity contents were used in the experimental production. Results showed Ikere -Ekiti kaolin and clay suitable for porcelain production. Values of standard refractory tests fell with in standard values for porcelain production.
\end{abstract}

Keywords Electrical Porcelain, Slip Casting, SW.Nigerian Kaolin

\section{Introduction}

Kaolin is commercial clay composed principally of the hydrated aluminosilicate clay mineral kaolinite. The commercial value of kaolin is based on the mineral's whiteness and fineness, but controllable particle size which may be optimized during processing. Particle size affects fluidity, strength, plasticity, colour, abrasiveness and ease of dispersion. Other important properties include the flat particle shape, which increases opacity and hiding power, its soft and non abrasive texture, due to the absence of coarser impurities, an its chemical inertness. These key properties distinguish kaolin from other kaolinitic clays like ball clay and fireclay. The kaolinite content of processed grades of kaolin varies, but is generally in the range of $75 \%$ to $94 \%$. Associated minerals may have considerable influence on the suitability of the clay for a particular application. Kao lin from different parts of the world have markedly different properties.

Kaolin has a chemical formu la of $\mathrm{Al}_{2} \mathrm{Si}_{2} \mathrm{O}_{5}(\mathrm{OH})_{4}$. It is non - plastic with a Mohr scale hardness of 2 to 2.5. It has a dull and earthy luster and a refractive index of $\alpha 1.553-1.565, \beta$ $1.559-1.569, \gamma 1.569-1.570$, with a specific gravity of 2.16 -2.68 . The melting te mperature is as high as over $1700^{\circ} \mathrm{C}$ and it is triclinic in its crystal system[1].

On the other hand, ball clay is an earth material of very fine particle size which forms as an end result of the the residue due to weathering or by hydrothermal action

* Corresponding author:

leke_oluwole@yahoo.co.uk (Oluwole O. O)

Published online at http://journal.sapub.org/ijmc

Copyright (C) 2012 Scientific \& Academic Publishing. All Rights Reserved which is a result of sedimentary deposit. Clay is cohesive and usually plastic when wet. It serves as a primary binder and fires in different colours depending on the types and compositions. It shrinks when dry and expands when wet. It is a poor conductor and that is why clay materials are used as thermal insulators. The chief clay minerals are kaolinites and montmorilonite and the impurities that are usually present are; silica, ferric oxide, chro miu m, magnesium, lime potash, beryllium, vanadium, tantalum and they mostly occur in oxide form. These impurities that are present in clay usually impact aesthetic qualities to raw and fired clays, which is of importance in Agriculture, Geology and Engineering. These clay materials, are used for making furnace linings, kilns, nozzles, stoves crucibles and ladles for pouring molten metal, heat exchangers and driers. There is ongoing research as to its suitability for car engine blocks. The presence of some of the impurities mentioned above makes the industrial application of clay possible, since these impurities possess the needed property, refractoriness; which is the temperature at which a material softens, melt or fuses. Clay materials are usually stable at high temperatures and this makes them have good thermal shock, i.e. ability to retain their original forms without cracking, spalling or flaking under sudden thermal changes and to have good resistance to environmental attack. It is their refractoriness and other properties like fusibility, poor heat and electrical conductivity, porosity, permeability, plasticity, slag resistance, which are expected for a clay material are determined by the type and quality of impurities and mineralcontents of such a clay, which in turn depends on the deposit and mode of formation of that particular clay. There has been concerted effort at assessing local clays with the intention of proffering possible industrial usage and 
possibility of blending $[7,8,9]$. The objective of this work therefore was to see the possibility of developing standard electrical porcelain from a blend of local raw clay materials.

\section{Materials and Method}

\subsection{Materials}

Kaolin and potter's clay samples from Ikere-Ekiti in Ekiti State, Kaolin from Iwo in Osun State and clay from Ile-Ife also in Osun state in Nigeria were collected for laboratory analyses. The che mical analyses of the clays were done using Atomic Absorption Spectrometer (AAS), and the results are presented in Table 1.

Table 1. Analysis of Iwo Kaolin,Ife Clay, Ikere Ekiti Kaolin and Clay

\begin{tabular}{|c|c|c|c|c|}
\hline Chemical & $\begin{array}{c}\text { Iwo } \\
\text { Kaolin }\end{array}$ & $\begin{array}{c}\text { Ile-Ife } \\
\text { Ball clay }\end{array}$ & $\begin{array}{c}\text { Ikere-Ekiti } \\
\text { kaolin }\end{array}$ & $\begin{array}{c}\text { Ikere-Ekiti } \\
\text { Ball clay }\end{array}$ \\
\hline $\mathrm{S}_{1} \mathrm{O}_{2}$ & 58.23 & 53.75 & 46.38 & 57.82 \\
\hline $\mathrm{Al}_{2} \mathrm{O}_{3}$ & 28.69 & 22.36 & 36.1 & 32.4 \\
\hline $\mathrm{TiO}_{2}$ & 2.81 & 2.17 & 0.72 & 1.8 \\
\hline $\mathrm{Fe}_{2} \mathrm{O}_{3}$ & 2.35 & 3.15 & 0.58 & 2.21 \\
\hline $\mathrm{CaO}$ & 1.21 & 1.66 & 0.05 & 0.37 \\
\hline $\mathrm{MgO}$ & 0.14 & 0.19 & 0.07 & 0.07 \\
\hline $\mathrm{K}_{2} \mathrm{O}$ & 3.01 & 4.82 & 0.46 & 2.33 \\
\hline $\mathrm{Na}_{2} \mathrm{O}$ & 0.52 & 0.69 & 0.06 & 0.41 \\
\hline $\mathrm{L} . \mathrm{O} . \mathrm{I}$ & 12.16 & 12.54 & 13.07 & 7.24 \\
\hline
\end{tabular}

\subsection{Method}

Close proximity of Iwo Kaolin and Ife clay to the Obafemi Awolowo University campus prompted the testing of the materials for possibility of their being useful for electrical porcelain production. Initial composition tests however showed that Iwo kaolin could not withstand the bisque firing, which was done at $900^{\circ} \mathrm{C}$, as the sample had lots of cracks. Thus it was abandoned as a candidate material for Kaolin production. Ekiti clay, known for high alu minosilicate content[5,7], hence high refractoriness [10,11], was used instead.

The samples used were of four different compositions. The compositions are: 35\% Ikere Ekiticlay, 30\% Ikere Ekiti Kaolin, 2.5\% Bentonite, 17\% Quartz, 12\% Feldspar and 3.5\% calciu m carbonate for sample A; 38\% Ikere Ekiti Clay, 24\% Ikere-Ekiti Kaolin, 20\% Quartz, and 18\% Feldspar for sample B; 34\% Ikere Ekiti clay, 26\% Ikere Ekiti Kaolin, 5\% Bentonite, 20\% Quartz, 13\% feldspar and 2\% calcium carbonate for sample C; 30\% Ikere Ekiti clay, 30\% Ikere Ekiti Kaolin, 2\% Bentonite, 20\% Quartz and 18\% feldspar for sample D.

Each of the four samples was subjected to standard refractory tests $[12,13]$. The tests performed were; dry and fired shrinkage, porosity, compressive strength and bulk density tests.

\subsubsection{Determination of Dry and Fired Shrinkage}

The samples were marked along a line, in order to maintain the same position after heat treat ment. A distance of $2 \mathrm{~cm}$ was measured with the vernier caliper as the initial length of the sample. The samples were air-dried for 24 hours and oven dried at $100^{\circ} \mathrm{C}$ for another 24 hours. The length at this stage was taken and was recorded as dry length. The samples were then fired to $1200^{\circ} \mathrm{C}$ for 6 hours. The samples were cooled to room temperature and the length measurements recorded.

The dry linear shrinkage and fired linear shrinkage were calculated from Equations (1) and (2)

$\%$ Dry shrinkage $=\left(\mathrm{L}_{\mathrm{w}}-\mathrm{L}_{\mathrm{d}}\right) / \mathrm{L}_{\mathrm{d}} \times 100 \%$

\%fried shrinkage $=\left(\mathrm{L}_{\mathrm{d}}-\mathrm{L}_{\mathrm{f}}\right) / \mathrm{L}_{\mathrm{f}} \times 100 \%$

where $L_{w}=$ wet length; $L_{f}=$ fired length; $L_{d}=$ Dry length

\subsubsection{Determination of Porosity}

After firing, the samples were soaked in a desiccator vacuum which was filled with water. However, the dry weights of the samples were taken before soaking in water. They were placed in a dessicator vacuum and evacuated and were left to soak for 2 hours. The samples were then removed and the soaked weights $\left(\mathrm{W}_{\mathrm{s}}\right)$ were taken. The expression for porosity is given in equation (3)

\%Porosity $=\left(\mathrm{W}_{\mathrm{s}}-\mathrm{W}_{\mathrm{d}}\right) / \mathrm{W}_{\mathrm{d}} \times 100 \%$

Where $\mathrm{W}_{\mathrm{s}}=$ soaked weight; $\mathrm{W}_{\mathrm{d}}=$ dry weight

\subsubsection{Determination of Compressive Strength}

Test pieces of the samples were prepared to a standard size of $633.47 \mathrm{~mm}^{2}$ cross sectional area on a flat surface. The samples were fired in a furnace at $1200^{\circ} \mathrm{C}$ and the temperature maintained for 5 hours. The samples were then cooled to room temperature. The specimens were placed on a compressive tester and load was applied axially by turning the hand wheel at a uniform rate until failure occurs. The manometer readings were recorded and compressive strength was calculated using equation (4).

Compressive strength $=$

Maximu m load/Cross-sectional area

\subsubsection{Determination of Bulk Density}

Prepared samples were air dried for 24 hours and oven dried at $100^{\circ} \mathrm{C}$, cooled in a dessiccator and weighed to the accuracy of $0.001 \mathrm{~g}$, after which the specimen was transferred to the beaker and heated for 30 minutes to assist in releasing the trapped air. The specimen was cooled and soaked weight $\left(\mathrm{W}_{\mathrm{s}}\right)$ taken. The specimen was then suspended in water using beaker placed on a balance. The suspended weight (S) was taken. The bulk density was calculated from equation (5)

$$
\text { Bulk Density }=\left(\mathrm{W}_{\mathrm{d}} \times \mathrm{D}_{\mathrm{w}}\right) /\left(\mathrm{W}_{\mathrm{s}}-\mathrm{S}\right)
$$

Where $\mathrm{W}_{\mathrm{d}}=$ Dry weight, $\mathrm{D}_{\mathrm{w}}=$ Density of water

$\mathrm{W}_{\mathrm{s}}=$ Soaked weight, $\mathrm{S}=$ Suspended weight

\subsubsection{Determination of Loss on Ignition}

$50 \mathrm{~g}$ of the sample was dried at $100^{\circ} \mathrm{C}$ and cooled in the desiccator. A porcelain crucible was cleaned, dried and weighed $\left(\mathrm{m}_{1}\right)$ to the nearest $0.001 \mathrm{~g}$. The dried sample was introduced into the crucible and the crucible together with the clay sample ions weighed $\left(\mathrm{m}_{2}{ }^{\prime}\right.$ to an accuracy of $0.001 \mathrm{~g}$. 
The crucible containing the clay sample was placed in a muffle furnace and heated to a te mperature of $100^{\circ} \mathrm{C}$ for three hours. The crucible and its contents were cooled in a desiccators and then weighed $\left(\mathrm{m}_{3}\right)$ to the nearest $0.001 \mathrm{~g}$. The Loss on Ignition (LO1) was calculated using equation (6)

Where $m_{1}=$ mass of porcelain crucible

$$
\text { L.O.I }=\frac{\left(\mathrm{m}_{2}-\mathrm{m}_{3}\right) \times 100 \%}{\left(\mathrm{~m}_{2}-\mathrm{m}_{1}\right)}
$$

$\mathrm{m}_{1=}$ mass of porcelain crucible

$\mathrm{m}_{2}=$ mass of sample and proclaim crucible

$\mathrm{m}_{3}=$ mass of fired clay sample and proclaim crucible

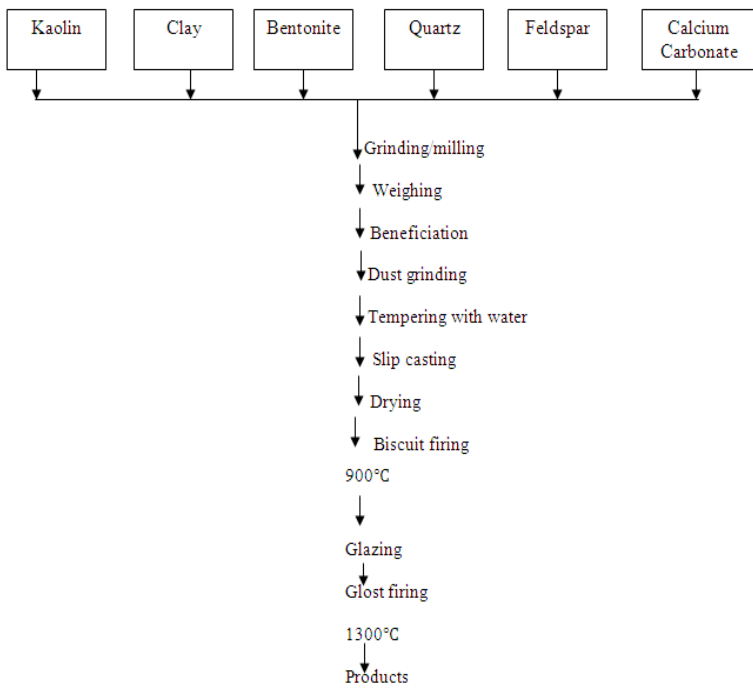

Figure 1. Electrical Porcelain production flow chart

\subsubsection{Electrical Porcelain Production}

The method used in the production of this electrical porcelain is slip casting. The slurry slip was cast into the plaster moulds of the insulator shape. After about 20 minutes, the excess slip in this case was drained off. The mould was opened and the insulator re moved and allowed to d ry at room temperature.

The electrical porcelain was dried at $100^{\circ} \mathrm{C}$ in the oven with accurate temperature control, after which it was fired to a bisque temperature of $900^{\circ} \mathrm{C}$. The porcelain was dipped in a glaze, after which it was dried and glost fired to $1300^{\circ} \mathrm{C}$. The process flow chart is as shown in Fig.1.

\section{Results and Discussions}

\subsection{Results}

Table 2 shows the values of some standard refractory tests performed on the four compoundments of Ikere-Ekiti kaolin and clay. Table 3 shows the comparative impurity content in Iwo and Ikere-Ekiti Kaolins,Ife and Ikere-Ekiti clays. Fig.2 shows the glazed and glost fired porcelain produced and Fig. 3 the biscuit fired, unglazed porcelain.

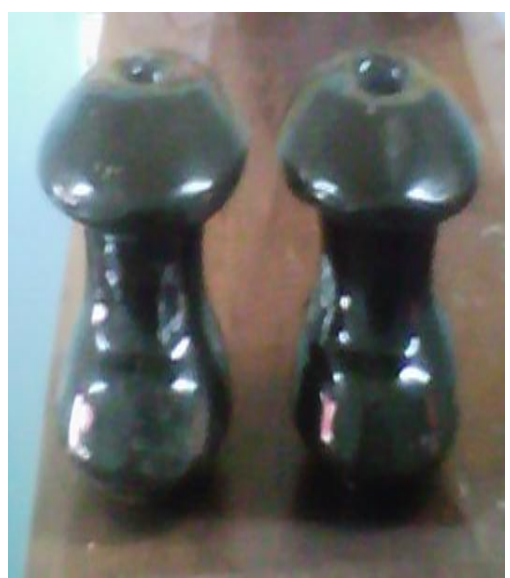

Figure 2. Glazed and glost fired electrical porcelain

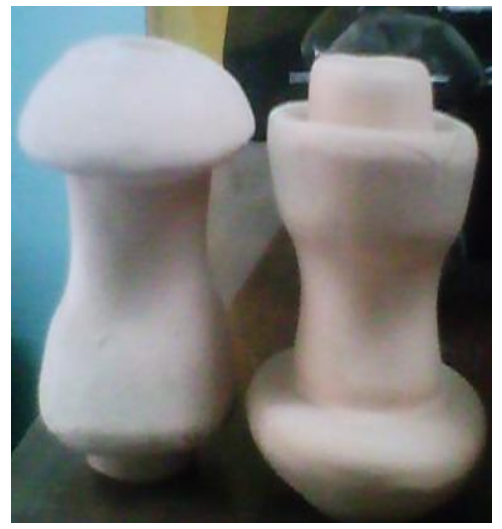

Figure 3. Unglazed Biscuit Fired Electrical Porcelain

Table 2. Values of Some Standard Refract ory Tests for the Four Compoundments of Ikere- Ekiti Kaolin and Clay

\begin{tabular}{|c|c|c|c|c|c|c|}
\hline Samples & Dry Shrinkage \% & Fired Shrinkage \% & Total Shrinkage \% & Porosity \% & Bulk Density $\left(\mathrm{g} / \mathrm{cm}^{3}\right)$ & Compressive Strength $\left(\mathrm{N} / \mathrm{mm}^{2}\right)$ \\
\hline A & 2.93 & 0.67 & 3.63 & 27.57 & 1.908 & 2.55 \\
\hline B & 2.56 & 2.63 & 5.26 & 28.5 & 2.1 & 2.69 \\
\hline C & 8.1 & 0.71 & 8.7 & 23 & 1.869 & 2.69 \\
\hline D & 1.87 & 0.5 & 2.4 & 23.65 & 1.847 & 2.69 \\
\hline
\end{tabular}

Table 3. Comparative Impurity Content in Iwo and Ikere-Ekiti Kaolins,Ife and Ikere-Ekiti clays

\begin{tabular}{|c|c|c|c|c|}
\hline Impurities & Iwo Kaolin & Ikere Ekiti Kaolin & Ile-Ife Clay & Ikere-Ekiti Clay \\
\hline $\mathrm{Fe}_{2} \mathrm{O}_{3}$ & 2.35 & 0.58 & 3.15 & 2.21 \\
\hline $\mathrm{K}_{2} \mathrm{O}$ & 3.01 & 0.46 & 4.82 & 2.33 \\
\hline $\mathrm{MgO}$ & 0.14 & 0.07 & 0.19 & 0.07 \\
\hline $\mathrm{CaO}$ & 1.21 & 0.05 & 1.66 & 0.37 \\
\hline $\mathrm{Na}_{2} \mathrm{O}$ & 0.52 & 0.06 & 0.69 & 0.4 \\
\hline
\end{tabular}




\subsection{Discussion of Results}

\subsubsection{Result of chemical Analysis}

Comparing the analysis of Iwo Kaolin with that of Ikere -Ekiti Kaolin, it could be seen that the percentage of impurities present in Iwo Kaolin is higher than that in Ikere- Ekiti Kaolin(Table 3). Ife clay could also be seen to have a higher impurity content compared with that of Ikere- Ekiti.

It could be inferred from the chemical analysis that the inability of Iwo Kaolin mixed with Ife Clay to withstand high temperature without cracking was due to the high proportion of impurities present. Also, the percentages of $\mathrm{A}_{2} \mathrm{O}_{3}$ in Ife clay (22.36) and Iwo Kaolin (28.69) are s maller than that of Ikere Ekiti Kaolin (36.10) and clay (32.40). It is established that the amount of $\mathrm{Al}_{2} \mathrm{O}_{3}$ present in clays affect refractoriness [8,9]. Iwo kaolin and Ile-ife clay were first used, but did not withstand the bisque firing, which was done at $900^{\circ} \mathrm{C}$, as the sample had lots of cracks.

\subsubsection{Bulk Density of the body}

Bulk density is an important property in porcelain wares. Bulk densities of the mixed samples lie within the range of 1.7 to $2.1 \mathrm{~g} / \mathrm{cm}^{3}$ which fall in standard requirements for porcelain body[2].

\subsubsection{Total shrinkage of the body}

It was observed that average total shrinkage for each of the samples was within the recommended value for porcelain production[14]. Higher shrinkage values result in warping and cracking of the porcelain wares resulting in los s or reduction in its strength.

\section{Conclusions}

Ikere -Ekiti kaolin and clay were found suitable for porcelain production. Values of standard refractory tests fell within standard values for porcelain production. The higher the percentage of impurities present in kaolin clay, the higher the tendency for the sample to crack while firing at high temperatures.

\section{REFERENCES}

[1] Deer, W. A., Howie, R. A., and Zussman, J. (1992). An introduction to the rock-forming minerals (2nd ed.). Harlow: Longman

[2] Ryan.W. (1978) “ Clay and Glazes for Potter” Pitman, London

[3] Jain, P.L (1979) "Principle of foundry technology". 2 ${ }^{\text {nd }}$ Edition.McGrawHill, New Delhi p. 325

[4] Rhodes, D (1979) "Clay and Glazes for potter" Pitman Publishers, London

[5] Beely, P.R (1982) "Foundry Technology" $3^{\text {rd }}$ Edition. Butterworth, London p.544

[6] Dehlinger, G (2000) "Science" Vol.290 p.227

[7] Omotoyinbo.J.A and O.O.Oluwole (2008) "Working Properties of Some Selected Refractory Clay Deposits in South Western Nigeria" Journal of Minerals and Materials Characterisation and Engineering, Michigan Technological University, USA. 7(3),233-245

[8] Olasupo.O.A and Borode.J.O (2009)'Development of Insulating Refractory Ramming Mass from Some Nigerian Refractory Raw Materials' Journal of Minerals \& Materials Characterization \& Engineering, Vol. 8, No.9, pp 667-678, 2009

[9] Atanda.P.O, Oluwole.O.O And Ogale.O.T(2008) “Adaptation Of Ushafa Clay, Abuja, as A Suitable Replacement For Bentonite In The Foundry Industry'Journal of Raw Materials Research, Raw Materials Research and Development Council,ABUJA.5(1\&2),53-60

[10] Jastrzebski, D.Z.(1982) “The nature and properties of Engineering Materials" $2^{\text {nd }}$ Edn.pp.338-343

[11] Hlavac, J. (1983) "The Technology of Glass and Ceramics, An Introduction" Elsevier Publishing, Amsterdam. Pp. 621

[12] Chesti. A.R (1986) "Refractories: Manufacture, Properties and Applications Prentice-Hall, New Delhi. p.155

[13] Hassan, S.B and Afewara, J.O.T (1994), "Refractory properties of some Nigerian clays" NSE Technical Transactions, 29(3), 13-19

[14] Chester, J.H (1973) "Refractories, Production and properties" The iron and steel institute, London, pg. 4- 13, 295-315. 